\title{
Legitimate Political Demands? How Young Russians of Different Political Orientation Assess Protests
}

\author{
Félix Krawatzek \\ Senior Researcher, Centre for East European and International Studies \\ (ZOiS), Berlin, Germany \\ felix.krawatzek@zois-berlin.de
}

\begin{abstract}
Popular unrest is a source of worry also for seemingly stable authoritarian regimes. Young faces have become the image of protest in Russia over the last two years, and they convey the importance of protests that may emerge in any authoritarian regime. Nevertheless, it remains unclear what kind of young people are taking to the street and how their mobilisation is judged by their peers. This paper draws on survey data from 2018 and 2019 on the political attitudes of young Russians alongside focus group interviews generated in 2019 in Yekaterinburg and St. Petersburg. The combination of these two sources allows us to explore the shifting assessments of political and environmental protests and young people's participation therein. It is argued that young Russians of different political orientation agree that Putin has been in power for too long and that also regime supporters do not, in principle, oppose regime critical protests. Rather, supporters insist on the importance for protests to be officially approved but question the genuine political nature of oppositional mobilisation. Friendship networks and institutional trust emerge as the key variables for understanding assessment of protests.
\end{abstract}

\section{Keywords}

Russia - protests - mixed-methods - authoritarian regimes

The global visibility of young people over the last years in protest movements shows the extent to which such protests have become a source of potential trouble for nondemocratic and democratic governments alike (Hollyer et al. 
2015, Svolik 2012). ${ }^{1}$ The symbol of youth and the actual mobilisation of young people have long played a central role in authoritarian and other illiberal regimes. Indeed, protests may affect how citizens evaluate politics, and they are therefore observed with great attention by the political elites. Protests may also influence what bystanders think about the regime, especially if the regime's response is judged inappropriate, for instance when excessive force is used. Inversely, if the protesters' behaviour is judged inappropriate - notably, due to the use of violence or the violation of the law - the political regime might gain in legitimacy (Frye and Borisova 2019). Because young people are more likely to participate in protests, some post-Soviet states have attempted to mobilise them in state-controlled movements. In order to pre-empt their desire to express themselves politically, the Russian regime has attempted to channel their political activities via pro-governmental youth organisations (Hemment 2012, Lassila 2012) and patriotic education (Sanina 2017).

This paper studies Russia - a relevant case study in its own right and an intriguing example for understanding the broader phenomenon of how illiberal regimes try to impact on their young cohort's political views. It is striking how young people - frequently of school age - have come to dominate the image of Russian protests since the presidential elections of 2018. Indeed, protests have become frequent and extremely diverse, relating to the uncovering of high-level corruption by Alexei Navalny and his team alongside numerous local protests that make specific demands - changes in the use of urban recreational areas, construction programmes affecting residential areas, or the management of waste. But even a high number of separate local protests will not necessarily translate into a broader movement against the regime (Lasnier 2018: 367 ). Meanwhile, this diversity in demands defies binary readings of Russian society being either pro- or anti-Putin.

The visibility of protests since 2018 significantly contrasts with what seemed like very little citizen activism, be this in demonstrations or civil society, in the former Warsaw Pact countries during the 199os (Bernhagen and Marsh 2007, Howard 2003), including youth activism (Ekiert and Kubik 1998, Vanhuysse 2004). Such a low level of activism has been the topic of more recent analysis on the local micro level, showing notably that Russians do actually not fit the box of being apathetic or activist, but are instead multifaceted

1 The author is grateful for research assistance provided by Kseniia Cherniak and Nadja Sieffert. Earlier versions of the paper were presented at the conference "Youth Mobilisation and Political Change: Participation, Values, and Policies Between East and West" in Berlin in November 2019. I am thankful for helpful comments provided by Nina Frieß, Sabine Kropp, Gwendolyn Sasse, and the two anonymous reviewers. 
(Clément et al. 2010). Meanwhile, global changes in the demands and strategies of protests have also affected Russia - a movement such as Fridays for Future has a small but vocal presence, and new forms of mobilisation, such as one-person pickets, have gained visibility via transnational social media.

This article argues that young people, even those who express support for the political system in place, lack enthusiasm for the current regime. The focus groups convey however deep divides between the different fractions of youth who diverge in their views on what kind of protest is legitimate and useful, and whether existing protests should be considered as being political in nature. This paper first discusses the literature on protests with a focus on Russia to develop three aspects related to protest legitimacy, the politicisation of protest, and the characteristics of protesters. It then goes on to present the data and analytic strategy, which is followed by a discussion of the results. First, it is argued that from 2018 to 2019 protests were increasingly seen as legitimate; over both years, friendship networks played a crucial role in explaining this assessment. Second, the question of the political nature of protest is an important topic of debate for the assessment of their legitimacy, and a strategy used by the authorities to dismiss protests as irrelevant. On the other hand, protesters themselves, while asserting the political nature of their activities, point out that they are not seeking radical political demands and instead de-politicise their claims. Third, to understand participation in protests, network effects are decisive, whereas socioeconomic variables play an insignificant role in understanding protest participation.

\section{Protest and Youth in Russia: What We Know}

The section begins with a discussion of the role of protests in contemporary Russia. It then proceeds to elaborate three specific themes for understanding how young people perceive of protests and their participation therein.

\section{The Russian Regime and the Importance of Protests}

Dissenting protests by young people are powerful symbols of a regime failing to relate to society. Time and again, young people mobilised against an established order have pressured politicians and contributed to the (near) downfall of political systems (Krawatzek 2018). Nevertheless, most protests, not only in Russia, do not lead to (regime) change. Instead, politicians either compensate or suppress protesters' demands - which might, however, shift the social contract (Feldmann and Mazepus 2018). 
Meanwhile, protests and the regime's responses allow for an understanding of intra-elite competition and contradictory views on the country's politics (Sakwa 2015). This pluralism among elites is even more exposed within society and is important to recognise, since oppositional protests do not simply lead to support for regime challengers. Although opposition protests tend to reduce support for the ruling regime (Hale and Colton 2017, Hollyer et al. 2015, Lohmann 1994) or contribute to disengagement, they do not need to raise the support for regime challengers, as the shift in opinion between the 2008 and 2012 Russian elections illustrate (Tertytchnaya 2019).

Elections are one key type of event that may lead to protests. Although elections in Russia and other post-Soviet countries see especially low turnout from young people, during elections these may express their political view also outside of the electoral arena. Put differently, even low-salience elections may raise the salience of politics in society, and therefore make political demands more likely to be voiced. In this way, elections - but also institutional changes or events perceived as having the potential for institutional change - can shift opportunity structures: "any event or broad social process that serves to undermine the calculations and assumptions on which the political establishment is structured occasions a shift in political opportunities" (McAdam 2010 [1982]: 41, original emphasis).

Overall, the opportunity structures that Russian (and, earlier, Soviet) activists face, have evolved considerably over time (Williams 2010). With a gradual policy shift in the aftermath of the 2011 State Duma elections, intimidation and public discrediting of oppositional figures have started to become more frequent. These policies differ in important ways from the co-optation and isolation of oppositional activists that marked earlier periods (Gel'man 2015: 77). In today's context, the opportunity structure is then severely limited with a high capacity and propensity for state repression. Activism is frequently forbidden, and protests are not authorised and often punished with short detentions. Protests involve the risk of suffering personal violence and require considerable personal commitment. Withdrawal from political mobilisation against the regime has therefore come to be the default response (Brunarska 2018: 318). Passivity seems like the most rational response to even the harshest economic or political crisis, since the personal benefit of protest tends to be largely outweighed by the personal cost. Thus, compliance, particularly in autocracies, prevails (Koesel and Bunce 2012). Nevertheless, when regional authorities initiated the construction of a church in the centre of Yekaterinburg, mass protests carried by young people spread across the city; likewise, when several opposition candidates were denied registration during the regional elections in September 2019, this gave rise to some of the most significant mobilisations of the last decade in Russia. 
Public opinion is another opportunity structure and hard to shift when the media landscape is one-sided and therefore does not allow information to circulate. In the Russian context, the media reiterates the interpretive master frames of the Kremlin itself; for alternative viewpoints, citizens have to turn to various online media. At the same time, it remains unclear whether the use of online media merely confirms pre-existing political opinions and behaviour or actually contributes to their change (Baumgartner \& Morris 2010, Johnson et al. 2010). As for civic activism, Gladarev and Lonkila, using online and offline ethnography, demonstrate how online and offline reinforce one another. The freedoms that VKontakte, the leading Russian social media site, offered around 2010 was critical for the recruitment, information, and mobilisation of activists (2012). Since the 2011-12 electoral cycle, however, the Russia authorities have started to increasingly control online media. In this expansion of "regulation", "sovereignisation", and "securitisation", traditional offline elites gained key positions of power (Asmolov and Kolozaridi 2017: 75). The way in which oppositional activists tend to self-frame their events highlights today's dominance of interpretive online and offline master frames. Nikolayenko, for instance, shows the centrality of patriotism during the 2014 marches against the military intervention in Donbas (2019).

Tellingly, the Moscow middle class has been characterised as embodying a weak demand for democracy combined with a reluctance to participate in mass actions (Dmitriev 2015). This silent majority, the attitudes of the broader population, influences how the regime can respond to protests, since public opinion matters to authoritarian regimes, which adopt certain policies in response to attitudes among citizens (Chen and Xu 2017, Greene and Robertson 2019, Truex 2016). Moreover, the silent majority indicates the extent to which people think they can change something in the environment they inhabit through protests (Brown 2016). Individuals who mobilise believe that their protest will make a difference (Goodwin and Jasper 2004), or at least influence their country's social contract.

\section{Legitimacy, Politicisation, and Participation}

Protests are often divisive and young people tend to have a clear view on whether they consider protests as legitimate or not. These assessments of the legitimacy of protests provide a foundation for views on the nature of protests and potential participation in them.

\section{Protest Legitimacy}

The social environment of young people is critical for understanding their view on protests. In that regard, friendship networks - and whether or not discussions 
therein are of a political nature - go a long way in understanding how a person relates to ongoing political events. Kharkhordin identifies an abundance of personal friendship in Russia, one that presupposes that both parties are genuine, equal, and disinterested (2016). These friendship circles are of political relevance as controversial political debates are indeed more common among friends and colleagues, than in the private family realm (Krawatzek and Sasse 2018: 6). Irrespective of whether such networks form political opinions, or whether previously held political opinions form networks, it is indisputable that there is significant convergence between the two (Lazer et al. 2010).

Alongside, trust in the political system is a crucial variable, although the precise relationship between political trust and protest legitimacy remains disputed (Hooghe and Marien 2012). While it seems plausible that a certain level of trust is required to think of protests as legitimate, just as any other form of engagement in the political process (Almond and Verba 1963), different mechanisms may apply in authoritarian regimes. Indeed, in such situations the inverse might work, with institutional distrust supporting views on protests as providing an alternative to the political processes in place.

Lastly, an individual's transnational contacts shape how she assesses her political surroundings. Young people, not only in Russia, are internationally connected, and the communication that takes places between them and their contacts abroad has the potential to impact the political values they express, for instance through political remittances (Itzigsohn and Villacrés 2008, Krawatzek and Müller-Funk 2019). Protest and political attitudes more broadly have been linked to different kinds of remittances, be these financial (Escribà-Folch et al. 2018) or social (Levitt 1998). Young Russians are aware of what is happening abroad, but it remains unclear whether their personal or mediated experiences make them more or less likely to endorse these other realities. To explore the transformative impact of transnational contacts, this paper includes an individual's propensity to migrate as a proxy for transnational contacts, assuming that the intention to migrate is a good indication of personal contacts and experiences abroad since migration - intended and realised - tends to closely relate to migratory networks (Haug 2008).

\section{Politicisation of Protest}

Second, is protest seen as actually being about political issues or rather dismissed as a social opportunity for young people? This aspect of the evaluation of protest links in important ways with the questions of legitimacy but takes place in a very specific Russian context. One strategy of the regime is to dismiss protests as not being about political issues, but rather as being carried by frustrated and isolated individuals or irresponsible teenagers. In this way, the 
Kremlin dismisses protests and civic activism more broadly as radical, rather than as reflecting legitimate political demands. Accordingly, the contours of acceptable civic activism are clearly defined, and citizens are expected to position themselves as supporting partners of the regime (Flikke 2016). This depoliticisation of protest as a strategy has important repercussions into broader society. It also adds to current literature, which has generally viewed protests as an expression of the politicisation of society. Authors have argued that the urban environment is itself a factor in the politicisation of citizens, since the latter need to engage with questions of inequality or redistribution in their locality (Dikeç 2017). Others have taken the general visibility of protests as indicating politicisation. Because protests capture media attention, they increase the visibility of the political in the public sphere and expand the number of actors involved in politics (Dolezal 2016). However, how citizens themselves engage with the question of politicisation, and how it impacts on their assessment of protest, has thus far been little studied.

\section{Protest Participation}

Third, what kind of individual overcomes the collective-action problem in a context in which it is nearly impossible to believe in a favourable response by the authorities? One relatively prominent factor identified in the literature are an individual's political values. People who self-position on the left are the ones who are more likely to participate in protest, although this relationship has varied over time (Opp et al. 1995, Torcal et al. 2016). Meanwhile, some level of trust is crucial for protest participation. Benson and Rochon demonstrate that interpersonal trust links with more positive assessments of the potential protest benefits and reduces the anticipated costs of protest participation (2004). Indeed, those who understand protest as being carried by more integrated members of a society, motivated by their belief in social justice, support this claim (McAdam 2010 [1982]) and argue that interpersonal trust relates positively to protest participation (Hetherington 1998). However, other parts of the literature have assumed that those who protest are disgruntled individuals (Buechler 2000), since people who feel alienated are less likely to participate in voting and other conventional political activities (Gilliam and Kaufmann 1998, Kuklinski and Chong 2001, Tate 2018). Moreover, institutional trust relates to protest participation. Individuals who express higher trust in a country's institutions are more likely to be involved in elections (Mishler and Rose 2005), whereas those with lower levels of trust seek other avenues for their political opinions. Protests may even increase levels of institutional trust, as individuals update their view on institutions (Frye and Borisova 2019). 
Another important aspect for understanding protest participation is the specific local context. Alongside the broader national mood, the local context plays into the kind of opportunity structures that individuals perceive and shapes political attitudes (Weatherford 1982). Local information is often more socially relevant, since it is endowed with emotions and can therefore be more easily remembered and related to (Weyland 2012). Under conditions of uncertainty, elements that allow recognition are helpful in enabling decision-making (Kahneman et al. 1982). Protests that take place in immediate proximity help citizens to update their information more than distant events, which are perceived as being potentially unrelated to one's own situation (Mazumder 2018). Meanwhile, the local context also sustains the social networks, which are at the core of any protest movement (Diani 2013). Accordingly, those among the Moscow middle class who were involved in the protests against elections in 2011 and 2012 played an important role in changing how neighbours and friends relate to the political system (Chaisty and Whitefield 2013, Dmitriev 2015, Robertson 2013). Moreover, as a comparison of Yaroslavl and Tatarstan has shown, the political attitudes of regional leaders matter in shaping the possibility and character of mobilisation (Brunarska 2018: 323).

\section{Data and Methods of Analysis}

This study uses two cross-sectional online surveys conducted among urban youth across Russian cities with more than one million inhabitants in April 2018 and April 2019. ${ }^{2}$ The young people included in the survey were aged between sixteen and thirty-four, and therefore cover a spectrum ranging from those who have never experienced a president other than Vladimir Putin to those who still have personal experience of the late Soviet Union and the 199os. The sample size was proportional to the size of the city population. A more or less vibrant university and associational life, which gives young people opportunities to get socially and politically involved, characterises all of these cities. Claims about changes over time in a cross-sectional survey are to be made with caution given the fact that individuals between the respective samples differ. In the present case, the quotas contributed to two samples that are identical in terms of age, gender, place of residence, income and employment

2 For more details, see Krawatzek and Sasse (2018). The cities include Moscow, St. Petersburg, Novosibirsk, Yekaterinburg, Kazan, Krasnoyarsk, Nizhniy Novgorod, Chelyabinsk, Omsk, Rostov-on-Don, Ufa, Samara, Voronezh, Perm and Volgograd. 
status. However, respondents in the 2019 sample indicated on average a lower level of education.

While surveys are most suited to understanding broader structures of public opinion, they are less able to get into the complex micro-foundations revealing the origins of political attitudes. This paper therefore complements the survey data through twelve focus groups conducted in two Russian cities. In June 2019, six groups were realised in Yekaterinburg and St. Petersburg respectively. In both cities, people were sampled into the groups based on two criteria: their political outlook and age. The first - political - dimension distinguished between those expressing support for, those opposed to, and those indifferent to the regime. People with these three distinct outlooks on the regime were kept separate to avoid self-censoring of potentially sensitive discussions. Along a second dimension, I distinguished participants by age, separating people aged $18-24$ and those aged $25^{-34}$. This resulted in six distinct focus groups with eight to ten participants in each of the two cities, giving a total of twelve groups, allowing for an understanding of the different social and political outlooks of young people with varying positions vis-à-vis the regime. A professional moderator conducted the groups, relying on a detailed questionnaire that I prepared and discussed with her beforehand. One significant section of the discussions explored questions of protest legitimacy, personal experience with protests, and views on pro-regime mobilisation. Each of the twelve groups lasted for around two hours. The focus groups were transcribed and coded with Maxqda to structure the material and assist in the interpretation. Combining focus group and quantitative analyses remains rare, although promising to understand protest (Dmitriev 2015).

\section{Results and Discussion}

\section{Protest as a Legitimate Form of Political Participation?}

Do young Russians consider protests as being legitimate? To answer this, the survey included the following question: "In principle, do you consider participation in protests a legitimate form of engagement?", offering a choice of three response options ("yes, in all cases", "yes, in some cases", "no, never"). Respondents could also skip the question (as all other survey questions). A split into three separate models conveys the complex relationship between institutional trust, friendship networks, and protest assessments, in particular for those who sometimes or never find protest legitimate. The three response categories were recoded as binary dependent variables for logistic regressions, and the main explanatory variables included those related to political trust 
(a binary variable for trust in the president and the use of state media as first or second source of information), friendship networks (a scale for the frequency of political discussions with friends, a dummy variable for whether an individual knows other people who participated in protests), and lastly a dummy variable to capture migration intentions. A conventional set of control variables was used, including one to capture whether the response came from 2019.

The probability of finding protests always legitimate in 2019 compared to 2018 substantively increased by more than two third, even if socioeconomic factors were controlled for (Table 1). Alongside a general increase in protest approval, factors related to political trust stand out, notably in relation to the president. High trust was expressed by individuals who were significantly less likely to always support protests, but it is intriguing that other young people with high trust are more likely to support some form of protest, raising the question of what kind of events people associate with protests. An additional factor was the consumption of state media. Respondents who did not consult state media were substantially more likely to disapprove of protests in general. This finding confirms the extent to which Russia's state-controlled media effectively separates the young population into different factions, leading to rather different views on present politics among them.

A second set of indicators related to an individual's personal networks. The survey asked about the frequency of political discussions with friends and colleagues and whether they knew people who participated in protests. These two factors are highly significant: having an acquaintance who has participated in protests doubles the probability of finding protests legitimate and the frequency of political discussions that young people engage in relates to one third higher probability of approving of protests. These two factors obviously interrelate and are likely to develop simultaneously.

The third feature concerns transnational contacts, expressed through an individual's propensity to migrate. Young Russians who desire to leave the country generally have a more positive view on the legitimacy of protests than their peers. Although political views do not necessarily predict migration behaviour, the intention to migrate conveys a person's embeddedness in transnational communicative network and a transnational outlook, which is itself a factor for understanding political views.

If we control for socioeconomic characteristics (Table 1, models 2, 4 and 6), the effects of the attitudinal variables do not vanish. Contrary to some of the findings in the literature discussed above, we find no effect for age, income, education, and being a student. However, being male increases the likelihood of viewing protest as legitimate. 


$\begin{array}{ccc}\text { Always logistic } & \begin{array}{c}\text { Sometimes } \\ \text { logistic }\end{array} & \text { Never } \\ \text { logistic }\end{array}$

$\begin{array}{lllll}(1) & (2) & \text { (3) }\end{array}$

(6)

\begin{tabular}{|c|c|c|c|c|c|c|}
\hline Year $2019(2019=1)$ & $\begin{array}{l}1.678 * * * \\
(0.185)\end{array}$ & $\begin{array}{l}1.734^{* * *} \\
(0.194)\end{array}$ & $\begin{array}{l}0.662^{* * *} \\
(0.065)\end{array}$ & $\begin{array}{l}0.666 * * * \\
(0.066)\end{array}$ & $\begin{array}{l}1.048 \\
(0.169)\end{array}$ & $\begin{array}{l}0.955 \\
(0.158)\end{array}$ \\
\hline Trust president (trust=1) & $\begin{array}{l}0.195^{* * *} \\
(0.023)\end{array}$ & $\begin{array}{l}0.199^{* * *} \\
(0.024)\end{array}$ & $\begin{array}{l}3.081^{* * *} \\
(0.320)\end{array}$ & $\begin{array}{l}3.082^{* * *} \\
(0.325)\end{array}$ & $\begin{array}{l}2.218 * * * \\
(0.428)\end{array}$ & $\begin{array}{l}2.151^{* * *} \\
(0.420)\end{array}$ \\
\hline State media $($ yes $=1)$ & $\begin{array}{l}0.710 * * \\
(0.081)\end{array}$ & $\begin{array}{l}0.721^{* *} \\
(0.084)\end{array}$ & $\begin{array}{c}1.113 \\
(0.116)\end{array}$ & $\begin{array}{c}1.142 \\
(0.123)\end{array}$ & $\begin{array}{l}1.827^{* *} \\
\left(0.35^{8}\right)\end{array}$ & $\begin{array}{l}1.662^{*} \\
(0.335)\end{array}$ \\
\hline $\begin{array}{l}\text { Frequency pol. discussions } \\
\text { with friends (scale from } 1 \text { to } 4 \text { ) }\end{array}$ & $\begin{array}{l}1.356^{* * *} \\
(0.091)\end{array}$ & $\begin{array}{l}1.296 * * * \\
(0.089)\end{array}$ & $\begin{array}{l}0.837^{* *} \\
(0.049)\end{array}$ & $\begin{array}{c}0.896 \\
(0.054)\end{array}$ & $\begin{array}{c}0.842 \\
(0.078)\end{array}$ & $\begin{array}{l}0.776^{* *} \\
(0.075)\end{array}$ \\
\hline $\begin{array}{l}\text { Acquaintance } \\
\text { protested }(\text { yes }=1)\end{array}$ & $\begin{array}{l}2.327^{* * *} \\
(0.308)\end{array}$ & $\begin{array}{l}2.255^{* * *} \\
(0.3 \circ 3)\end{array}$ & $\begin{array}{l}0.540^{* * *} \\
(0.068)\end{array}$ & $\begin{array}{l}0.548^{* * *} \\
(0.070)\end{array}$ & $\begin{array}{l}0.446^{* *} \\
(0.135)\end{array}$ & $\begin{array}{l}0.453^{* *} \\
(0.137)\end{array}$ \\
\hline Intention to migrate (yes=1) & $\begin{array}{l}1.347^{*} \\
(0.163)\end{array}$ & $\begin{array}{l}1.428^{* *} \\
(0.177)\end{array}$ & $\begin{array}{c}0.987 \\
(0.104)\end{array}$ & $\begin{array}{c}0.907 \\
(0.098)\end{array}$ & $\begin{array}{l}0.609 * * \\
(0.099)\end{array}$ & $\begin{array}{l}0.659^{*} \\
(0.111)\end{array}$ \\
\hline Under 25 (yes $=1)$ & & $\begin{array}{c}1.221 \\
(0.182)\end{array}$ & & $\begin{array}{c}0.942 \\
(0.127)\end{array}$ & & $\begin{array}{c}0.763 \\
(0.179)\end{array}$ \\
\hline Gender $($ male $=1)$ & & $\begin{array}{c}1.568 * * * \\
(0.181)\end{array}$ & & $\begin{array}{c}0.706 * * * \\
(0.072)\end{array}$ & & $\begin{array}{c}0.960 \\
(0.162)\end{array}$ \\
\hline High disposable income (yes=1) & & $\begin{array}{c}1.091 \\
(0.160)\end{array}$ & & $\begin{array}{c}0.786 \\
(0.102)\end{array}$ & & $\begin{array}{c}1.459 \\
(0.289)\end{array}$ \\
\hline Education (scale from 1 to 4 ) & & $\begin{array}{c}1.055 \\
(0.065)\end{array}$ & & $\begin{array}{c}0.984 \\
(0.054)\end{array}$ & & $\begin{array}{c}0.940 \\
(0.085)\end{array}$ \\
\hline Student (yes=1) & & $\begin{array}{c}0.908 \\
(0.176)\end{array}$ & & $\begin{array}{c}1.266 \\
(0.221)\end{array}$ & & $\begin{array}{c}0.5^{6} 7 \\
(0.189)\end{array}$ \\
\hline Constant & $\begin{array}{l}0.271^{* * *} \\
(0.066)\end{array}$ & $\begin{array}{l}0.181^{* * *} \\
(0.061)\end{array}$ & $\begin{array}{l}1.688^{*} \\
(0.360)\end{array}$ & $\begin{array}{l}1.85^{*} \\
\left(0.55^{2}\right)\end{array}$ & $\begin{array}{c}0.092^{* * *} \\
(0.032)\end{array}$ & $\begin{array}{l}0.164^{* * *} \\
(0.080)\end{array}$ \\
\hline Observations & 1,984 & 1,951 & 1,984 & 1,951 & 1,984 & 1,951 \\
\hline Log. likelihood & $-1,013.123$ & -991.517 & $-1,221.104$ & $-1,19 \circ .3 \circ 5$ & -568.170 & -547.198 \\
\hline Akaike inf. crit. & $2,040.245$ & $2,007.034$ & $2,456.209$ & $2,404.610$ & $1,15 \circ .339$ & $1,118.395$ \\
\hline
\end{tabular}

Note: ${ }^{*} \mathrm{p}<0.05 ;{ }^{* *} \mathrm{p}<0.01 ;{ }^{* * * *} \mathrm{p}<0.001$ 
The focus group material enriches these patterns. In the groups, the legitimacy of different kinds of protests was triggered with a picture from one of Navalny's anti-corruption marches. Although protests in Russia do not simply map on to a Navalny-Putin dichotomy, this picture was one that everyone could relate to and it provided an effective trigger for the discussion of protest attitudes more broadly. The second picture exemplified a pro-government mobilisation, in this case one of the Immortal Regiment marches. These commemorative marches started as a grass-roots initiative and were subsequently co-opted by the Russian state (Fedor 2017).

Young people agreed, irrespective of their political preferences, that Putin has been in power for too long. There was, however, significant disagreement on whether or not protests were an appropriate response to that situation. Among participants in the groups who self-identified as supporters and indifferent, opinions ranged from outright opposition to protest as a practice of political expression to the belief that protests were pointless, since they were unlikely to lead to change. Participants in both groups who had no personal contact to someone who had protested questioned the legitimacy of any kind of mobilisation. And those who were not opposed in principle would argue that it was pointless. As ETf $31^{3}$ mentioned: "It [the aim] is not clear from the posters. Here is the official aim: 'He is not our tsar'. Oh well, once this tsar is overthrown, another one will come along."

A conviction that protesters were paid also delegitimised protests in the eyes of regime supporters. This consensual interpretation in the regime-supporting focus groups conveys how one of the frames used in Russian state media has travelled into young people's minds. Inversely, individuals who had participated in protests either criticised a biased media or had completely stopped following state-controlled media. AKm2o, a respondent from Yekaterinburg, dismissed state media as "unreliable", and AAm 28 felt that it was impossible to find "any decent news", since only a few internet resources were credible.

The limitations of state media were a concern shared by some in the pro-regime or indifferent groups. They acknowledged that the media failed to provide equal access, and distorted political and social developments. In Yekaterinburg, demonstrations against the building of a church had taken place just prior to the focus group interviews. These were on everyone's mind and contributed to the impression of a distorted media coverage. According to $\mathrm{EFf}_{24}$, a member of the indifferent group: "everyone knew about the rally for the square. But looking at how it was covered in the news across the country, it

3 Focus group participants are referred to by their initials, their gender ( $m=m a l e, f=f e m a l e)$ and age. 
was barely mentioned. I think it is really problematic to find out about rallies in the country if you do not search purposefully and do not have friends there."

The quantitative evidence indicates that supporters of the regime sometimes approve of protests. In the pro-regime groups, people also spoke about the importance of criticising the authorities on specific points.

MLf34: I believe citizens must express their positions. They must express their support for the government if they really think that the government is good.... If they oppose it, then they should go and say that they are against some aspect. But you cannot be against the system, because one is part of the system, and the system will not change anyway. But you should express your opinion with others, so that your ideas are conveyed to the authorities.

A recurring theme among regime supporters was the need for protests to be approved. They opposed what they perceived as radical, disorderly, and chaotic mass mobilisation. Regime-supportive AKfi8 expressed an opinion shared by many in her group, namely that, while protest is probably the only way to put pressure on the government, only approved protests are legitimate expressions of society. Moreover, she opposed any use of violence during protests, and suggested that opposition could be expressed through art, rather than aggression.

Speaking to the role of friendship networks, those who had already participated in protests, or had friends who have been involved, expressed a generally positive view on protests of any kind. They justified this with reference to their friends' motivations and their deep frustration with Putin's long tenure and what they perceived as a corrupt political system. DIm27 explained:

I believe that everyone is hurt, that is to say, I do not think that people come to rallies for some selfish reasons. There are political beliefs, I mean, sometimes to genuinely support someone there. Here, people are really dissatisfied with the government, so they come out and show this.

And along similar lines:

AShm18: This [protests] is the only effective way to influence the government at the moment, because we do not have any meaningful elections. Nobody is going to listen to an opinion you express on the internet, in letters or other messages. Only a rally can clearly show the state of mass opinion, and a rally puts pressure on the government. 
These friendship networks are a key factor in what people make of protests. Young people regularly referred to friends who went on the street and who were sincerely committed. These network effects shape the evaluation of protests, as statements from St. Petersburg illustrate. EKm32: "As a rule, it is only pro-government rallies that are being paid for. As I know, people who come out to [oppositional] rallies are genuinely doing so on their own initiative." And $\mathrm{IBf}_{33}$ from the regime critical group claimed such sincerity also for the Immortal Regiment marches with reference to her grandmother: "I think it [the mobilisation] is sincere. Personally, my grandmother always goes, and for her this is a way to preserve the real memory." Supporters of the regime were aware of these network effects and therefore criticised protesting young people precisely for only getting involved because of friends they wanted to shout along with. YuKhm33 sarcastically claimed that many young people overcome their isolation by protesting, by "standing around and shouting whatever".

The international component shined through some focus groups. The "Yellow Vests" protest in France, for instance, received media attention in Russia in early 2019. However, those who knew about these protests did not necessarily endorse them. Rather, citing the violence of the French "Yellow Vests" served the supporters of the Russian regime as proof that protests tend to be chaotic, uncoordinated, and eventually pointless. The intention to migrate that individuals stated during the groups could not, however, be related to their attitudes regarding protests.

Even young people who support the regime on paper share the opinion that Putin has been in power for too long and do not necessarily question the legitimacy of protest. Instead, they also criticise the authorities but insist on the need to get official approval for protests, out of fear of chaos and violence. The importance for friendship networks in the evaluation of protests is conveyed in the quantitative and qualitative data alongside the increase in protest approval from 2018 to 2019 . From the question of whether or not protests have a political legitimacy ensues the following discussion about protest assessments.

\section{Political Grievances or Social Desires: Politicised Protest(ers)?}

Is participation in protest carried by politicised individuals or rather, as often claimed by Russian authorities, by individuals who simply disrespect established norms? And are protests seen as an expression of the politicisation of society or dismissed as a waste of time? Regarding politicisation, the discussions that took place during the focus groups reveal much about the dynamics among young Russians today. The debate over the political nature of protest, or its lack, is itself a key component in the interpretive struggle over whether or not protests are legitimate. Local activists in Russia tend to frame their own 
engagement as non-political and some even consider themselves as politically indifferent when they get involved in activism addressing local shortcomings. Rare are those activists who openly make their claims in political narratives (Tykanova and Khokhlova 2013).

Young people who have protested, however, are clearly convinced of the political nature of protests. They point to the country's political shortcomings as their reason for protest. AKm29 mentioned the "monarchical system", and EKm32 summarised their effort to resist and change the system: "Against corruption, against stagnation, but for Russia." In the same group of regime critics, another person mentioned the "faked elections" as the reason for his own involvement and underlined that, in his view, an electorally driven change of power was needed, adding that this was not going to come without civil unrest. He projected this attitude onto the rest of the population, claiming that "people no longer want to feel that they are being fooled". Such criticism about a lack of evolution and political stagnation were frequent, and when prompted with the picture taken during the Navalny demonstration, ASf22 stated: "In the picture, there is a cyborg [printed on one of the placards]. This expresses that we are treated like children, but we have already grown up, and nothing has changed, nothing has happened, there is strictly no improvement. People themselves try to bring something in, but they are not allowed to do so."

A slightly longer discussion between older focus group participants underlines the importance of protests precisely because of their political nature.

AAm28: This is despair, anger, hatred, simply because how much can you fool people? This was the situation after the elections. They understand that they were fooled. The results of the election were simply drawn on a piece of paper. Nobody wanted to make him be the president.

ITm3o: Well, seventy percent voted for him according to some organisations.

AAm28: Yes, but then I read a post that it was no more than thirty percent and that the numbers were then changed. They are not timid; they are spreading their vision. They are fooling us right in front of our eyes. Every day they spit on our soul. Clearly, people are already tired of enduring this. And how much of it can you endure?

M: What do you think drives them? Why did they take to the streets?

ITm3o: I think that people really want a change of government, simply because one person has been in there for such a long time.... It seems to me that in a normal state there should be a change of power and people should go on the street to demand something very normal. 
Along similar lines, AKm22 claimed that protesters wanted to "assert their rights", and for LEf23 they desired an "improvement of their living conditions". Many agreed with the latter's claim that "everything [has] deteriorated" during Putin's reign and that, by implication, "if his rule is extended, we need to change the system".

Opposed to this interpretation of the political character of protests were the views in the two other groups. Among those that self-identified as being politically indifferent, somewhat vague expressions and a clear lack of knowledge about protests stood out. Participants in that group rarely expressed support for Putin, but also felt that he had ruled for too long. However, they tended to argue that protests were "breaking things down" (VPf29) and not constructive. What is important, however, is that the various groups hardly differed in terms of what they expected from the government. When prompted to discuss political issues, they agreed that it would be desirable that Russia becomes a "normal country", which young people linked with a rotation of political power.

Nevertheless, differences of views within the indifferent and regimesupportive groups were bound to be large. The older participants in the indifferent group in St. Petersburg, for instance, acknowledged the political nature of protests, but they added that these protests were pointless, since nothing was going to change in response to street mobilisation. $\mathrm{LPf}_{2} 8$ approved of people expressing their dissatisfaction with Putin, but added: "as you can see, these rallies did not help; we still have our great good president". IKf 30 stated ironically that young people could sometimes gather without being punished, and therefore "the political power must be good".

The age of protesters was a frequent topic of debate in the indifferent (and pro-regime) groups. Here, the young age of the protesters tended to delegitimise the protests. ETf31 exclaimed: "Look at their age, some of them are only schoolchildren!" Others, commenting on the protesters' youth, claimed that they simply followed a herd (YuKhm33), or even ridiculed them as "zombified" (NPm26). Asked about a possible dialogue with youth, ETf 31 dismissed their demands:

Someone agitated them. Among them, there are no conscientious adults. The thing is that a wise politician has been building our political system for years now. It is simply impossible to set the country on a new path in four to eight years; much more time is required for that. And they [the youth] watched him "rule" for years, and have now decided that they need to overthrow the tsar. Put a new one in place. But who really believes that a new person would change the situation in Russia within a year? 
Among the indifferent and in particular the regime-loyal young people, a central line of criticism was the unpolitical nature of protests. These young people did not accept the politicisation of protest. They remarked instead that the young people who got involved were simply driven by excitement rather than the pursuit of a genuine political goal. YuSf 23 argued: "To me it seems that some of them do not have that genuine outrage on their face. Instead, they simply derive pleasure from their involvement. They do not want to show their position. Instead they are simply emotional and search for this kind of adrenaline." Others criticised the carnivalesque and event-like nature of protests (AKf21, AGf25).

Among regime supporters, such statements were frequent and convey their little understanding of and interest for protests of any kind. Protests were dismissed as irrelevant, and their political nature was disputed. AKfig claimed that she "looked at this [the Navalny protests] from the outside", based on which she concluded that "this is all nonsense" and that she does "not understand them in these rallies", wondering in relation to demands for fair elections: "what do they want all the time?". Supporters of the regime also claimed repeatedly that participation in protests was a source of income. ESf3o argued: "Money motivates them. They were paid, so they went out." A last way of depoliticising the protests by those opposed to mobilisation was to stress that protesters were frustrated individuals. Regime supporters argued that people were simply unhappy with their lives rather than with the political system as such (EFf29), or that the protesters' demands were opaque (IDm24).

The focus groups convey in a striking way that only a very small number of individuals is against the protests because they genuinely support the political regime in place. Even those who voted for the current president agree with some regime-critical viewpoints, although they would expect that anti-governmental demonstrations should be authorised: regime-loyal AKfi8 acknowledged that

this [protests] is probably the only direct opportunity for people to influence the government in some way, because other options, such as through deputies, are not very effective. So people need to do it [protest]. But at the same time, it should be authorised, not like Mr Navalny's rallies, which led to nothing but agitating the crowd.

Similarly, VPf 29 from the indifferent group in St. Petersburg stated that people generally took to the streets too late and that protest was therefore becoming meaningless - however, she also underlined that in her opinion people had the right to question the state, to express their opinions freely and to try to achieve a compromise with the state. 


\section{What Kind of Person Does It Take to Protest?}

What are the characteristics of individuals who participate in protests? The survey included questions enquiring into political and social as well as environmental protests, which were dummy-coded to perform a logistic regression using standard socioeconomic indicators as control variables. A second set of models (Table 2, models 3 and 4) extended the analysis to understand what factors other than socioeconomic indicators - political values, trust and local context - link with protest behaviour.

The probability of having participated in any kind of protest was more than $50 \%$ higher in 2019 compared to 2018 (Table 2, models 1 and 2). Furthermore, in both years, people younger than twenty-five were more likely to participate in protests, with a larger effect for political protests. Men were twice as likely to get involved in political protests, with no gender distinction for environmental protests. Those with a higher self-declared purchasing power were more than twice as likely to be involved in environmental protests, but not in political protests. Level of education or being a student was not statistically significant in the analysis.

If we extend the model to include other socio-political factors (Table 2, models 3 and 4), the effects of age disappear, and the role of gender and income weakens. Instead, the role of the three dimensions of political values, trust and local context stands out. Respondents who agreed with multiculturalist viewpoints were twice as likely to have participated in protests of any kind. ${ }^{4}$ Among protest participants in the focus groups in St. Petersburg, SFf 24 reflected a somewhat multicultural outlook when she criticised the imposition of religiosity, which the controversy over the church building in Yekaterinburg illustrated:

I am now personally concerned about the issue of how churches and temples are being built in Yekaterinburg, and how parks are demolished. We have a cult of churches. There is a lot of attention paid to this, and I think it is wrong. I believe that this is an imposition on our society, which also consists of atheists. But instead, we continue to build very many churches.

4 For this variable we constructed an index including responses to two statements: "The state should require Russian firms to put in an extra effort to bring immigrants from the near abroad into their company" and "Children of immigrants and refugees should have the right to be taught their native language in addition to their ordinary classes in Russian." We then determined the mean response value, and individuals who were more than one standard deviation away from the mean were coded as 1. 
Dependent variable: Protest participation

$\begin{array}{cccc}\text { Environmental } & \text { Political Social } & \text { Environmental } & \text { Political Social } \\ \text { logistic } & \text { logistic } & \text { logistic } & \text { logistic }\end{array}$

(1)

(2)

(3)

(4)

\begin{tabular}{|c|c|c|c|c|}
\hline Year $2019(2019=1)$ & $\begin{array}{l}1.550^{*} \\
(0.270)\end{array}$ & $\begin{array}{l}1.644^{* *} \\
(0.308)\end{array}$ & $\begin{array}{l}1.730^{* *} \\
(0.362)\end{array}$ & $\begin{array}{l}1.856^{*} \\
(0.456)\end{array}$ \\
\hline Under 25 (yes=1) & $\begin{array}{l}1.53^{*} \\
(0.330)\end{array}$ & $\begin{array}{l}1.994^{* *} \\
(0.443)\end{array}$ & $\begin{array}{c}1.078 \\
(0.283)\end{array}$ & $\begin{array}{c}1.430 \\
(0.407)\end{array}$ \\
\hline Gender $($ male $=1)$ & $\begin{array}{c}0.995 \\
(0.175)\end{array}$ & $\begin{array}{c}2.220^{* * *} \\
(0.447)\end{array}$ & $\begin{array}{c}0.796 \\
(0.166)\end{array}$ & $\begin{array}{l}1.637^{*} \\
(0.411)\end{array}$ \\
\hline $\begin{array}{l}\text { High disposable income } \\
(\text { yes=1) }\end{array}$ & $\begin{array}{c}2.356^{* * *} \\
\left(0.45^{2}\right)\end{array}$ & $\begin{array}{c}1.363 \\
(0.300)\end{array}$ & $\begin{array}{l}2.009^{* *} \\
(0.465)\end{array}$ & $\begin{array}{c}0.913 \\
(0.268)\end{array}$ \\
\hline $\begin{array}{l}\text { Education (scale from } 1 \\
\text { to } 4 \text { ) }\end{array}$ & $\begin{array}{c}0.938 \\
(0.089)\end{array}$ & $\begin{array}{c}1.101 \\
(0.111)\end{array}$ & $\begin{array}{c}0.807 \\
(0.090)\end{array}$ & $\begin{array}{c}0.926 \\
(0.124)\end{array}$ \\
\hline Student (yes=1) & $\begin{array}{c}0.733 \\
(0.208)\end{array}$ & $\begin{array}{c}0.815 \\
(0.238)\end{array}$ & $\begin{array}{c}0.831 \\
(0.280)\end{array}$ & $\begin{array}{c}0.603 \\
(0.237)\end{array}$ \\
\hline $\begin{array}{l}\text { Multicultural views } \\
(\text { agreement }=1)\end{array}$ & & & $\begin{array}{c}2.069^{* * *} \\
(0.445)\end{array}$ & $\begin{array}{l}1.901^{*} \\
(0.493)\end{array}$ \\
\hline Trust president (trust=1) & & & $\begin{array}{l}0.666 \\
(0.141)\end{array}$ & $\begin{array}{l}0.360^{* * *} \\
(0.098)\end{array}$ \\
\hline Trust unknown (trust=1) & & & $\begin{array}{c}1.519 \\
(0.344)\end{array}$ & $\begin{array}{c}1.544 \\
(0.418)\end{array}$ \\
\hline $\begin{array}{l}\text { City with high protest } \\
\text { density }^{5} \text { (yes }=1 \text { ) }\end{array}$ & & & $\begin{array}{c}1.5^{29} \\
(0.359)\end{array}$ & $\begin{array}{c}0.998 \\
(0.290)\end{array}$ \\
\hline $\begin{array}{l}\text { Frequency pol. discussions } \\
\text { with friends (scale from }\end{array}$ & & & $\begin{array}{l}1.68 \mathrm{o}^{* * *} \\
(0.227)\end{array}$ & $\begin{array}{l}1.655^{* *} \\
(0.266)\end{array}$ \\
\hline 1 to 4$)$ & & & & \\
\hline $\begin{array}{l}\text { Member of a youth } \\
\text { organisation }(\text { yes = } 1 \text { ) }\end{array}$ & & & $\begin{array}{l}3.079^{* * *} \\
(0.925)\end{array}$ & $\begin{array}{c}2.016 \\
(0.787)\end{array}$ \\
\hline $\begin{array}{l}\text { Acquaintance protested } \\
(\text { yes }=1)\end{array}$ & & & $\begin{array}{l}2.128^{* * *} \\
(0.464)\end{array}$ & $\begin{array}{c}15 \cdot 518 * * * \\
(4.222)\end{array}$ \\
\hline
\end{tabular}

5 The intensity of protests in a city reflects a ranking of the relative share of total inhabitants and participants in Navalny protests in 2017 and 2018. High protest density cities are Yekaterinburg, Chelyabinsk, Omsk, and Perm. 
TABLE 2 Protest participation (cont.)

Dependent variable: Protest participation

\section{Environmental Political Social Environmental Political Social logistic logistic logistic}

(1)

(3)

(4)

$\begin{array}{lcccc}\text { Constant } & 0.044^{* * *} & 0.015^{* * *} & 0.013^{* * *} & 0.003^{* * *} \\ \text { Observations } & (0.017) & (0.007) & (0.008) & (0.002) \\ \text { Log. likelihood } & 2,296 & 2,281 & 1,55^{8} & 1,55^{1} \\ \text { Akaike inf. crit. } & -533.514 & -475.423 & -379.601 & -266.351 \\ & 1,083.027 & 966.847 & 787.201 & 560.702\end{array}$

Note: ${ }^{*} \mathrm{p}<0.05 ;{ }^{* *} \mathrm{p}<0.01 ;{ }^{* * *} \mathrm{p}<0.001$

Related to the two dimensions of trust - institutional and interpersonal - trust in the president significantly predicts participation in political protests, but is unrelated to environmental protests. Trust in unknown people, as an expression of interpersonal trust, increases the likelihood of participation in environmental protests. Although the variables are not statistically significant, the effect is sizeable and might nevertheless speak to the idea that protests are carried by those who feel integrated in society, rather than isolated and disgruntled individuals.

Concerning an individual's local and social context, young people who maintain frequent political discussions with friends or have friends who have participated in protests are substantively more likely to participate in protests of any kind themselves, particularly political protests, speaking to the profound importance of friendship discussed by Kharkhordin (2016). AAm28, a protest participant in the group in Yekaterinburg observed:

At first I went with a friend just to provide him company when he criticised the politics. He said to me "Shall we go to the meeting?", and then I came along and somehow I started to watch more news. Not on TV but instead on the internet. And I began to read much more. And when I hear someone speak about a rally, I know that I have to go out and engage with the people. 
Membership in youth organisations is a place where young people form friendship networks, also in state-controlled ones (Hemment 2012). Membership in any type of youth organisation has a sizeable effect on participation in environmental protest, speaking to the involvement of young Russians in activities that are less openly against the political system but seek instead to address issues of common concern, such as pollution or the use of forests. Indeed, youth organisations, particularly those concerned with the protection of the local environment, remain important across Russia and are less targeted by political surveillance than overtly political organisations. Contrary to what one might expect from the literature, the size of protests in one's city of residence does not relate to protest participation. Protest networks in Russian cities are therefore distinct from broader local networks, illustrating the somewhat fragmented civic structure.

\section{Little Demand for Radical Politics: A Fragmented and Disillusioned Youth}

Russia's young generation is of an extremely heterogeneous character, which the combined analysis of survey and focus group material allows to explore. Looking at their attitudes to protests, I argue that this fragmentation is due less to socioeconomic variables than to the kind of friendship networks that young people maintain and their assessments of the political system. Whether someone has friends who protested and whether one engages in political discussions with them matters more than income, education or age. Meanwhile, the view on protest legitimacy in 2019 is significantly more positive than in 2018. The focus groups reveal that even among supporters of the regime protests may be considered legitimate. Indeed, among some regime supporters there is no opposition to protests, even against the government, as long as these are authorised.

The authorisation of protest provides a link between most of the young people analysed in this study. It is striking that there is very little desire for radical mobilisation, which reflects on the power of the Russian state to determine what is considered appropriate civic activism. Young activists seek the rhetoric of depoliticisation to create a space in which they can act - such as the Fridays for Future movement in Russia or local activism (Tykanova and Khokhlova 2013). At the same time, the focus groups underline that the seal of a genuine political nature of protests is fiercely disputed: regime critical young people argue for the genuine political demands that mobilisation voiced, and supporters of the regime frequently dismiss mobilisation as illustrating personal frustration. The discussion of politicisation is part of the evaluation of protests 
and links closely with various other considerations such as the young age of many protesters or the suspicion that activists are paid.

Furthermore, this paper contributes to an understanding of what kinds of people actually get involved in environmental and political-social protests. In this regard, only gender and income matter among the socioeconomic indicators. Rather, the most important drivers are political values, such as a multiculturalist outlook. Moreover, it is institutional trust in the Russian institutions - notably the president - rather than interpersonal trust that links with protest participation. Lastly, it is personal networks - political discussions and contacts with other protesters - that explain who takes to the street.

These different evaluations of protests and the Russian political system have profound implications. They speak to the foundations on which the current regime is constructed. The political assessments of young people are diverse, and even those who appear as supporters on paper lack enthusiasm for Putin's Russia. Nevertheless, they are unlikely to take to the street as they are just as disillusioned with the violence of which they accuse the "opposition" as they are with those in power. A general sense of political disillusion can be identified in the focus groups. In the words of VEf21: “They don't listen and nothing changes anyway." This situation shows the affective void that exists in today's political setting. Protesters, on the other hand, are passionate about their opposition to Putin, and they have withdrawn from the official Russian environment in several ways - notably, through their disengagement from state-controlled media and retreat into semi-public spheres of discussion, revolving around friends and family members.

\section{Bibliography}

Almond, Gabriel A. \& Verba, Sidney. (1963). The Civic Culture: Political Attitudes and Democracy in Five Nations, Princeton, NJ: Princeton University Press.

Asmolov, Gregory \& Kolozaridi, Polina. (2017). The Imaginaries of RuNet: The Change of the Elites and the Construction of Online Space. Russian Politics, 2:1, pp. 54-79.

Baumgartner, Jody \& Morris, Jonathan. (2010). MyFaceTube Politics: Social Networking Web Sites and Political Engagement of Young Adults. Social Science Computer Review 28.1, pp. 24-44.

Benson, Michelle \& Rochon, Thomas. (2004). Interpersonal Trust and the Magnitude of Protest: A Micro and Macro Level Approach. Comparative Political Studies, 37:4, pp. $435^{-57}$. 
Bernhagen, Patrick \& Marsh, Michael. (2007). Voting and Protesting: Explaining Citizen Participation in Old and New European Democracies. Democratisation, 14:1, pp. 44-72.

Brown, Kate Pride. (2016). The Prospectus of Activism: Discerning and Delimiting Imagined Possibility. Social Movement Studies, 15:6, pp. 547-6o.

Brunarska, Zuzanna. (2018). Understanding Sociopolitical Engagement of Society in Russia: A View from Yaroslavl Oblast and Tatarstan. Problems of Post-Communism, 65:5, pp. 315-26.

Buechler, Steven. (200o). Social Movements in Advanced Capitalism: The Political Economy and Cultural Construction of Social Activism, Oxford: Oxford University Press.

Chaisty, Paul \& Whitefield, Stephen. (2013). Forward to Democracy or Back to Authoritarianism? The Attitudinal Bases of Mass Support for the Russian Election Protests of 2011-2012. Post-Soviet Affairs, 29:5, pp. 387-403.

Chen, Jidong \& Xu, Yiqing. (2017). Why Do Authoritarian Regimes Allow Citizens to Voice Opinions Publicly? 79:3, pp. 792-8o3.

Clément, Carine, Miryasova, Olga \& Demidov, Andrey. (2010) Obyvatel'skiy mir. In: Clément, S., Miryasova, O. \& Demidov, A. (eds.) Ot obyvateley kaktivistam, pp. 27-57 Moscow: Tri kvadrata.

Diani, Mario. (2013). Networks and Social Movements. In: Snow, D., Della Porta, D., Klandermans, B. \& McAdam, D. (eds.) The Wiley-Blackwell Encyclopedia of Social and Political Movements, https://doi.org/10.1002/9780470674871.wbespm438. Hoboken, NJ: Wiley.

Dikeç, Mustafa \& Swyngedouw, Erik. (2017). Theorizing the Politicizing City. International Journal of Urban Regional Research, 41:1, pp. 1-18.

Dmitriev, Mikhail. (2015). Lost in Transition? The Geography of Protests and Attitude Change in Russia. Europe-Asia Studies, 67:2, pp. 224-43.

Dolezal, Martin; Hutter, Swen \& Becker, Regina. (2016). Protesting European Integration: Politicisation from Below? In: Hutter, S., Grande, E. \& Kriesi, H. (eds.) Politicising Europe: Integration and Mass Politics, pp. 112-34. Cambridge: Cambridge University Press.

Ekiert, Grzegorz \& Kubik, Jan. (1998). Collective Protest in Post-Communist Poland, 1989-1993: A Research Report. Communist and Post-Communist Studies, 31:2, pp. 91-117.

Escribà-Folch, Abel; Meseguer, Covadonga \& Wright, Joseph. (2018). Remittances and Protest in Dictatorships. American Journal of Political Science, 62:4, pp. 889-904.

Fedor, Julie. (2017). Memory, Kinship, and the Mobilization of the Dead: The Russian State and the "Immortal Regiment" Movement. In: Fedor, J., Kangaspuro, M., Lassila, J. \& Zhurzhenko, T. (eds.) War and Memory in Russia, Ukraine and Belarus, pp. 30745. Basingstoke: Palgrave Macmillan. 
Feldmann, Magnus \& Mazepus, Honorata. (2018). State-Society Relations and the Sources of Support for the Putin Regime: Bridging Political Culture and Social Contract Theory. East European Politics, 34:1, pp. 57-76.

Flikke, Geir. (2016). Resurgent Authoritarianism: The Case of Russia's New NGO Legislation. Post-Soviet Affairs, 32:2, pp. 103-31.

Frye, Timothy \& Borisova, Ekaterina. (2019). Elections, Protest, and Trust in Government: A

Natural Experiment from Russia. The Journal of Politics, 81:3, pp. 820-32.

Gel'man, Vladimir. (2015). The Politics of Fear: How the Russian Regime Confronts Its Opponents. Russian Politics and Law, 53:5-6, pp. 6-26.

Gilliam, Franklin \& Kaufmann, Karen. (1998). Is There an Empowerment Life Cycle? Long-Term Black Empowerment and Its Influence on Voter Participation. Urban Affairs Review, 33:6, pp. 741-66.

Gladarev, Boris \& Lonkila, Markku. (2012). The Role of Social Networking Sites in Civic Activism in Russia and Finland. Europe-Asia Studies, 64:8, pp. 1375-94.

Goodwin, Jeff \& Jasper, James M. (eds.). (2004). Rethinking Social Movements: Structure, Meaning, and Emotion, Lanham, Md.: Rowman \& Littlefield Publishers.

Greene, Samuel \& Robertson, Graeme. (2019). Putin v. the People: The Perilous Politics of a Divided Russia, New Haven, CT: Yale University Press.

Hale, Henry \& Colton, Timothy. (2017). Who Defects? Unpacking a Defection Cascade from Russia's Dominant Party 2008-12. American Political Science Review, 111:2, pp. $322-37$.

Haug, Sonja. (2008). Migration Networks and Migration Decision-Making. Journal of Ethnic and Migration Studies, 34:4, pp. 585-6o5.

Hemment, Julie. (2012). Nashi, Youth Voluntarism, and Potemkin NGOs: Making Sense of Civil Society in Post-Soviet Russia. Slavic Review, 71:2, pp. 234-6o.

Hetherington, Marc. (1998). The Political Relevance of Political Trust. American Political Science Review, 92:4, pp. 791-808.

Hollyer, James; Rosendorff, Peter \& Vreeland, James Raymond. (2015). Transparency, Protest, and Autocratic Instability. American Political Science Review, 109:4, pp. 764-84.

Hooghe, Marc \& Marien, Sofie. (2012). A Comparative Analysis of the Relation between Political Trust and Forms of Political Participation in Europe. European Societies, 15:1, pp. 131-52.

Howard, Marc. (2003). The Weakness of Civil Society in Post-Communist Europe, Cambridge: Cambridge University Press.

Itzigsohn, José \& Villacrés, Daniela. (2008). Migrant Political Transnationalism and the Practice of Democracy: Dominican External Voting Rights and Salvadoran Home Town Associations. Ethnic and Racial Studies, 31:4, pp. 664-86. 
Johnson, Thomas, Zhang, Weiwu \& Bichard, Shannon. (2010) United We Stand? Online Social Network Sites and Civic Engagement. In: Papacharissi, Z. (ed.) A Networked Self, pp. 193-215 Abingdon: Routledge.

Kahneman, Daniel; Slovic, Paul \& Tversky, Amos. (1982). Judgment Under Uncertainty: Heuristics and Biases, Cambridge: Cambridge University Press.

Kharkhordin, Oleg. (2016). Friendship and Politics in Russia. Common Knowledge, 22:2, pp. $220-36$.

Koesel, Karrie \& Bunce, Valerie. (2012). Putin, Popular Protests, and Political Trajectories in Russia: A Comparative Perspective. Post-Soviet Affairs, 28:4, pp. 403-23.

Krawatzek, Félix. (2018). Youth in Regime Crisis: Comparative Perspectives from Russia to Weimar Germany, Oxford: Oxford University Press.

Krawatzek, Félix \& Müller-Funk, Lea. (2019). Two Centuries of Flows between "Here" and "There": Political Remittances and Their Transformative Potential. Journal of Ethnic and Migration Studies, 46:6, pp. 1003-24.

Krawatzek, Félix \& Sasse, Gwendolyn. (2018). Youth in Russia: Outlook on Life and Political Attitudes. ZOiS Report.

Kuklinski, James \& Chong, Dennis (eds.). (2001). Citizens and Politics: Perspectives from Political Psychology, Cambridge: Cambridge University Press.

Lasnier, Virginie. (2018). Russia's Opposition Movement Five Years After Bolotnaia: The Electoral Trap? Problems of Post-Communism, 65:5, pp. 359-71.

Lassila, Jussi. (2012). The Quest for an Ideal Youth in Putin's Russia II: The Search for Distinctive Conformism in the Political Communication of Nashi, 2005-2009, Stuttgart: Ibidem-Verlag.

Lazer, David; Rubineau, Brian; Chetkovich, Carol; Katz, Nancy \& Neblo, Michael. (2010). The Coevolution of Networks and Political Attitudes. Political Communication, 27:3, pp. 248-74.

Levitt, Peggy. (1998). Social Remittances: Migration Driven Local-Level Forms of Cultural Diffusion. International Migration Review, 32:4, pp. 926-48.

Lohmann, Susanne. (1994). The Dynamics of Informational Cascades: The Monday Demonstrations in Leipzig, East Germany, 1989-91. World Politics, 47:1, pp. 42-101.

Mazumder, Soumyajit. (2018). The Persistent Effect of U.S. Civil Rights Protests on Political Attitudes. 62:4, pp. 922-35.

McAdam, Doug. (2010 [1982]). Political Process and the Development of Black Insurgency, 1930-1970, Chicago: University of Chicago Press.

Mishler, William \& Rose, Richard. (2005). What Are the Political Consequences of Trust?: A Test of Cultural and Institutional Theories in Russia. Comparative Political Studies, 38:9, pp. 1050-78.

Nikolayenko, Olena. (2019). Framing and Counter-Framing a Peace March in Russia: The Use of Twitter during a Hybrid War. Social Movement Studies, pp. 1-20. 
Opp, Karl-Dieter; Finkel, Steven; Muller, Edward; Wolfsfeld, Gadi; Dietz, Henry \& Green, Jerrold. (1995). Left-Right Ideology and Collective Political Action: A Comparative Analysis of Germany, Israel, and Peru. In: Jenkins, C. (ed.) The Politics of Social Protest, pp. 35-53. Abingdon: Routledge.

Robertson, Graeme. (2013). Protesting Putinism: The Election Protests of 2011-2012 in Broader Perspective. Problems of Post-Communism, 6o:2, pp. 11-23.

Sakwa, Richard. (2015). Questioning Control and Contestation in Late Putinite Russia. Europe-Asia Studies, 67:2, pp. 192-208.

Sanina, Anna. (2017). Patriotic Education in Contemporary Russia: Sociological Studies in the Making of the Post-Soviet Citizen, Stuttgart: ibidem-Verlag.

Svolik, Milan. (2012). The Politics of Authoritarian Rule, Cambridge: Cambridge University Press.

Tate, Katherine. (2018). Black Faces in the Mirror: African Americans and Their Representatives in the US Congress, Princeton, NJ: Princeton University Press.

Tertytchnaya, Katerina. (2019). Protests and Voter Defections in Electoral Autocracies: Evidence from Russia. Comparative Political Studies, https://doi. org/10.1177/oo10414019843556.

Torcal, Mariano; Rodon, Toni \& Hierro, María José. (2016). Word on the Street: The Persistence of Leftist-Dominated Protest in Europe. West European Politics, 39:2, pp. $326-5$ o.

Truex, Rory. (2016). Making Autocracy Work: Representation and Responsiveness in Modern China, Cambridge: Cambridge University Press.

Tykanova, Elena \& Khokhlova, Anisya. (2013). Local Communities in St. Petersburg: Politicisation of Claims to Contested Urban Spaces. Articulo-Journal of Urban Research, 4, pp. 1-19.

Vanhuysse, Pieter. (2004). East European Protest Politics in the Early 199os: Comparative Trends and Preliminary Theories. Europe-Asia Studies, 56:3, pp. 421-38.

Weatherford, Stephen. (1982). Interpersonal Networks and Political Behavior. American Journal of Political Science, 26:1, pp. 117-43.

Weyland, Kurt. (2012). The Arab Spring: Why the Surprising Similarities with the Revolutionary Wave of 1848 ? Perspectives on Politics, 10:4, pp. 917-34.

Williams, Gregory. (2010). When Opportunity Structure Knocks: Social Movements in the Soviet Union and Russian Federation. Social Movement Studies, 9:4, pp. 443-6o. 